\title{
Variation in the root mass of ryegrass types and its ecological consequences
}

\author{
G. C. Ennik and T. Baan Hofman
}

Centre for Agrobiological Research (CABO), P.O. Box 14, 6700 AA Wageningen, Netherlands

Key-words: (perennial) ryegrass, root mass, shoot/root ratio, defoliation, $\mathrm{N}$ supply, genetic variation, competitive ability, couchgrass.

\section{Summary}

- The shoot/root ratio of grass in the vegetative phase is constant under constant conditions.

- With intermittent $\mathrm{N}$ supply root mass and shoot/root ratio of grass in monoculture vary widely. Both relatively and absolutely, root mass is larger than with full $\mathrm{N}$ supply.

- Short periods of low $\mathrm{N}$ supply suffice to give a marked increase in root growth.

- Under constant environmental conditions root mass is closely related to the frequency of defoliation.

- Considerable genetic variation in root mass exists between clones of perennial ryegrass. The differences are largest under conditions of maximum root growth.

- Root mass is positively related to competitive ability.

\section{Introduction}

The production of root mass of plants is governed partly by their genetic constitution, partly by the environmental conditions. Previous work on clones of perennial ryegrass revealed a marked difference in root mass for clones with a similar shoot production (Baan Hofman \& Ennik, 1980), resulting in different shoot/root ratios. As in other species, the shoot/root ratio of ryegrass depends on the nitrogen supply and is affected by defoliation. Grassland is generally harvested several times a year and in accordance fertilized with nitrogen repeatedly. A number of experiments has been set up to examine the effect of fluctuating nitrogen supply and recurring defoliation on the size of the root mass of various clones. The ecological significance of the genetic or environment-induced variation in root size for the competitive ability and the tolerance towards environmental stress will be discussed.

\section{Materials and methods}

The clones and selections of perennial ryegrass used in the trials were provided by 
the Foundation for Agricultural Plant Breeding (SVP) at Wageningen. When planted at the start of the experiments separate tillers were taken from an established sward and cut to a height of about $8 \mathrm{~cm}$; the roots were removed almost completely. Fertilizer and water were supplied in amounts assumed to meet the requirements of the plants. At harvesting the plants were cut to a height of about $2 \mathrm{~cm}$. In this paper the term shoot refers sometimes to the above-ground parts harvested without the stubbles, sometimes to the total above-ground parts, stubbles included, which is indicated in the diagrams.

\section{Results and discussion}

\section{Effect of $N$ on root mass and shoot/root ratio}

When nitrogen supply in grassland is suboptimal, it usually means that after harvesting ample nitrogen is available at the beginning of the regrowth period, but that nitrogen is short at the end of that period. The effect of such a fluctuating nitrogen supply was shown by Ennik et al. (1980) in a pot trial with Italian ryegrass (Lolium multiflorum Lam.) (Fig. 1). With full N supply shoot and root grew in proportion and the shoot/root ratio was the same for all pots. With fluctuating $\mathrm{N}$ supply shoot growth was limited to the same level for all pots, but root growth varied widely. Therefore the shoot/root ratio also varied widely. With full $\mathrm{N}$ supply root mass was not only relatively, but also absolutely smaller than with fluctuating (i.e. limiting) $\mathrm{N}$ supply.

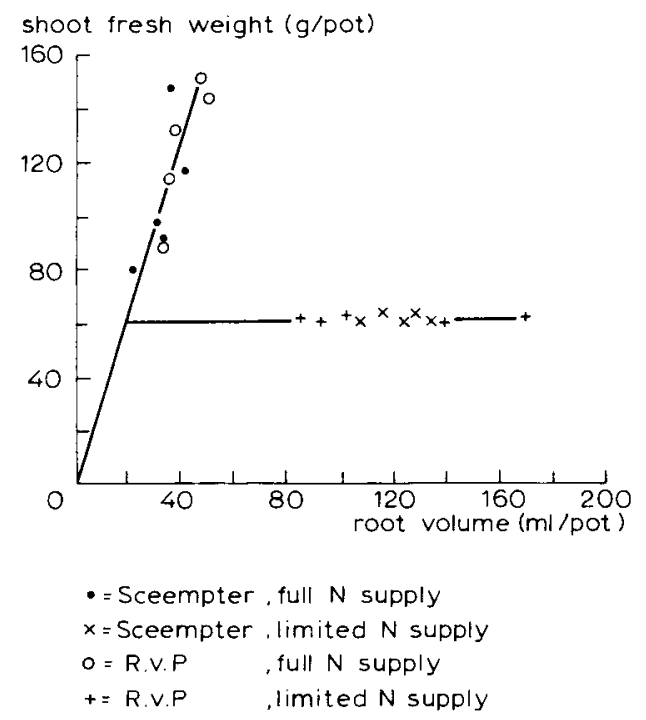

Fig. 1. Effect of $\mathrm{N}$ supply on shoot and root mass of Italian-ryegrass cultivars 'Sceempter' and 'R.v.P.', grown in monoculture on weekly changed nutrient solution. Two $\mathrm{N}$ levels: full supply, and $\mathrm{N}$-exhausted towards the middle of the week. Root volume measured by the method of water displacement. Last cut of 4-month-old crop, defoliated every 4 weeks; 5 replicates per treatment (Ennik et al., 1980). 
Similar results were obtained in a field trial with perennial ryegrass (Lolium perenne L.), in which nitrogen was applied at levels of 165 to $660 \mathrm{~kg}$ per ha per year (Ennik et al., 1980). At a given $\mathrm{N}$ supply shoot mass was always the same, whereas the corresponding root mass varied widely. This may indicate that, in spite of the high dressings, the availability of $\mathrm{N}$ for shoot growth was suboptimal at certain moments, for instance at the end of the growing period or during dry spells, allowing an increase in root growth. Similar increases in root mass can also occur, if other soil factors are limiting, for instance phosphate or water (Brouwer, 1962). It was shown by Ennik et al. (1980) in a pot trial that short periods of diminished $\mathrm{N}$ supply, combined with a slightly raised temperature and reduced irradiation, sufficed already to give a marked increase in root growth.

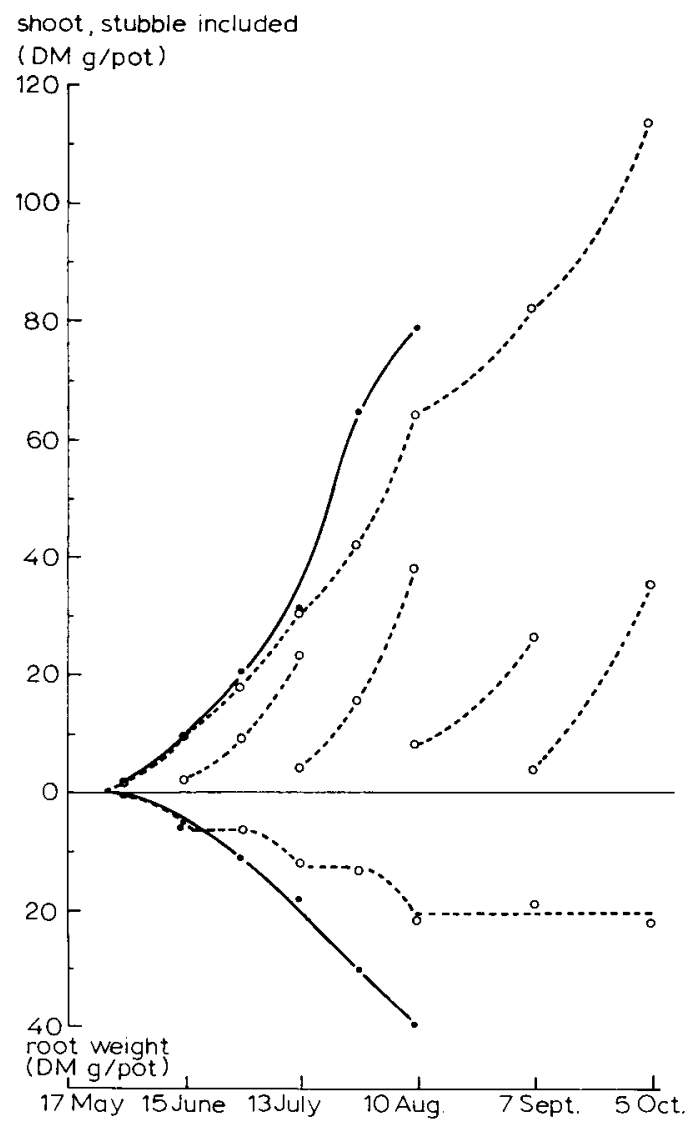

Fig. 2. Shoot and root dry-matter (DM) production of perennial ryegrass on soil in pots after uninterrupted growth (solid lines) or a 4-week cutting regime (dashed lines). Shoot yields separated per cut or accumulated over all cuts. Averages of 2 pots per treatment (modified after Ennik, 1966). 


\section{Effect of frequency of defoliation on root mass}

The shoot/root ratio of ryegrass in the vegetative phase remains the same under constant conditions, but it is disturbed by defoliation. The effect of repeated defoliation on root mass as compared with undisturbed growth is shown in Fig. 2. Shoot yield of the defoliated grass is given per cut as well as cumulative. After each defoliation root growth stops until the original shoot/root ratio has been restored. After three harvests the period between two defoliations was fully needed to restore the original shoot/root ratio (Ennik, 1966). Henceforth root mass did not increase further. With the 4-week cutting in this trial the maximum root mass was about half that of undisturbed growth at this time. The diagram shows that root mass was relatively more affected by defoliation than shoot mass.

\section{Genetic variation in root mass of perennial ryegrass in monoculture}

The genetic variation in root mass was studied in 6 perennial ryegrass clones (Baan Hofman \& Ennik, 1980: Exp. 7). Clone 39 was characterized by a large root mass, clone 40 by a small root mass, clone 52 and three other clones were intermediate. The difference in root mass and shoot/root ratio was absent at the first cut, but became apparent during the season. With almost similar herbage yields in the fourth cut, the root mass of clone 39 was about three times that of clone 40 .

In another trial with clones 39, 40 and 52 similar results were obtained. The shoot-root relationships at three cuts are shown in Fig. 3 (upper part). At the first cut a straight line through the origin is found: all clones have the same shoot/root ratio. At later cuts the points are grouped around a more horizontal line, not going through the origin; clone 39 has the largest root mass and clone 40 the smallest. Because of the difference in root mass the shoot/root ratio of the clones is also different.

The effect of $\mathrm{N}$ supply on the root mass of clones 39 and 40 was further investigated by Blanken (1983) ${ }^{1}$. In Fig. 4 annual shoot yield is plotted against final root weight for eight $\mathrm{N}$ levels. Root weight increased at the lower $\mathrm{N}$ rates and decreased at the higher $\mathrm{N}$ rates, whereas shoot weight was still increasing, though at the highest $\mathrm{N}$ rate maximum shoot production was almost reached. At each $\mathrm{N}$ level shoot production was similar for the two clones, but root production differed markedly, clone 39 outyielding clone 40 at all $\mathrm{N}$ levels. The difference was small at the lower $\mathrm{N}$ rates and greatest at the $\mathrm{N}$ rate for maximum root growth. The difference decreased at the higher $\mathrm{N}$ rates, but was nevertheless still present at the highest rate.

\section{Effect of root mass on competitive ability}

The relation between root mass and competitive ability was studied by comparing growth of a number of clones in monoculture and in mixtures.

Fig. 3 (lower part) shows the relation between shoot and root mass of 3 clones growing by twos in mixture without and with partitioning of the root systems. In contrast with the situation in monoculture (Fig. 3, upper part), shoot mass of the

1 Experiment carried out during Master of Science study at the Department of Field Crops and Grassland Husbandry of the Agricultural University at Wageningen. 

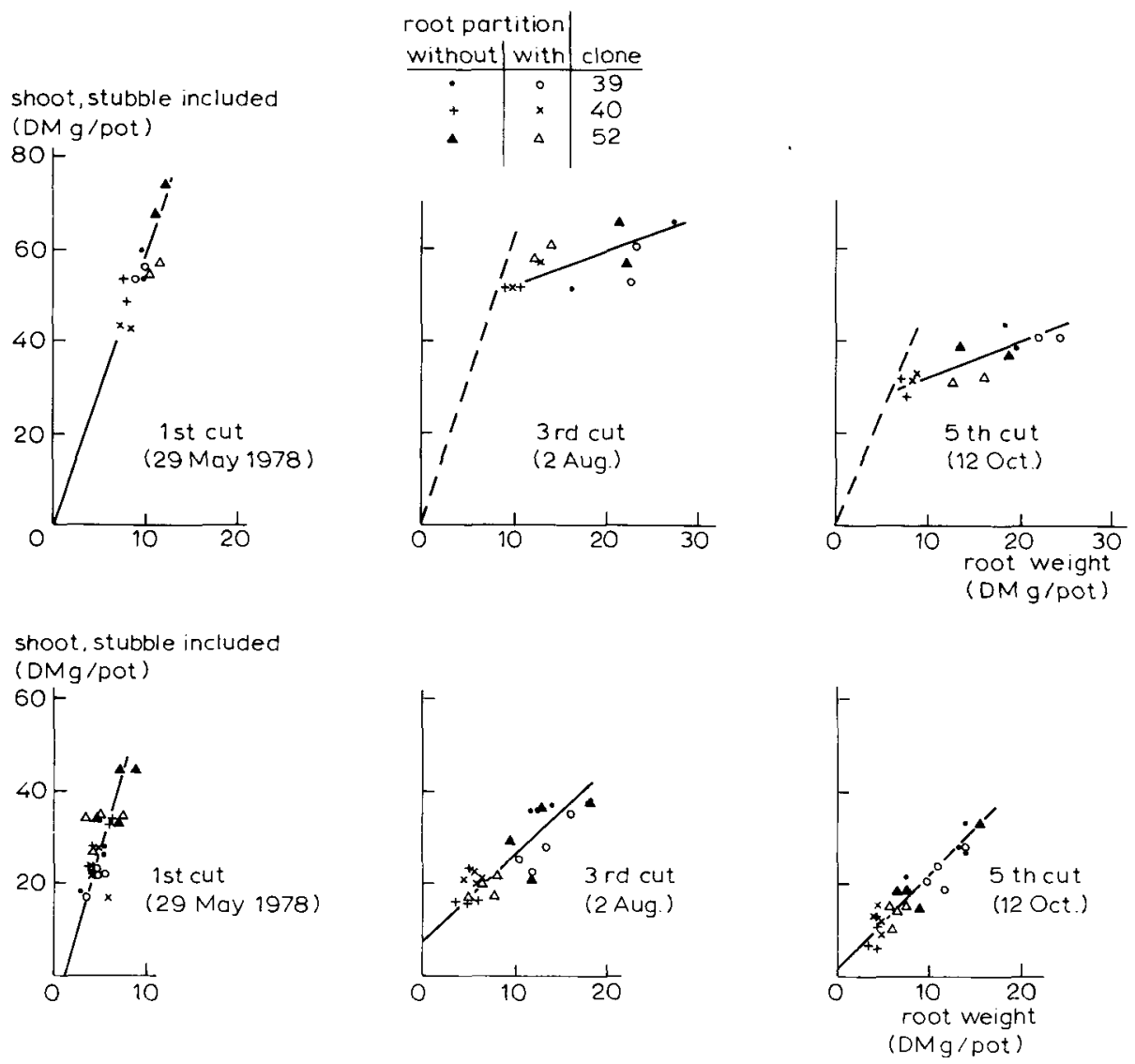

Fig. 3. Upper part: shoot-root relationship in the 1st, 3rd and 5th cuts of 3 ryegrass clones in monoculture, with and without partitioning of the soil into 4 quadrants; 2 replicates per treatment. Lower part: as above, but for the clones growing in mixture. All combinations of 2 clones per pot, one clone in 2 opposite quadrants and another clone in the other 2 quadrants.

Planted outdoors in sandy soil in Mitscherlich pots on 31 March, 1978; 4 clusters of 5 tillers per pot. N, P and $\mathrm{K}$ fertilizer were supplied at planting and after each cut, with the exception of $P$ and $K$ after the 4 th cut; total dressings were $1300 \mathrm{~kg} \mathrm{~N}, 875 \mathrm{~kg} \mathrm{P}_{2} \mathrm{O}_{5}$ and $875 \mathrm{~kg} \mathrm{~K}{ }_{2} \mathrm{O}$ per ha (Trial 516.06).

different clones in mixture was almost proportional to root mass and the shoot/root ratio was about the same for all clones. The production of the individual clones in mixture was different, depending on their competitive ability. Clone 40 is the lowest producer in mixture and so the weakest competitor. Clone 39 is the highest producer and so the strongest competitor. The results suggest that competitive ability is related to root mass, the clone with the smallest root mass in monoculture being the weakest competitor in mixture, and that with the largest root mass in monoculture the strongest competitor in mixture. In the later cuts the yield of clone 39 is larger without than with root partitioning, and the yield of clone 40 smaller. This indicates 


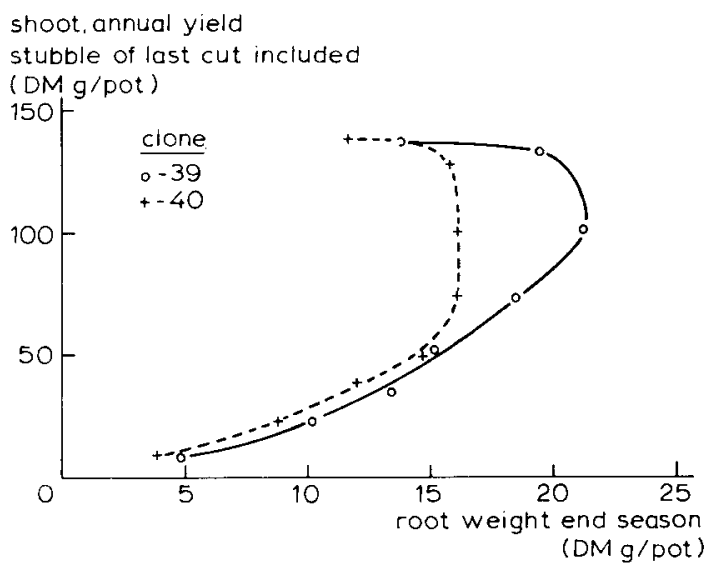

Fig. 4. Shoot-root relation of ryegrass clones 39 and 40 (grown on soil in pots, diameter $20 \mathrm{~cm}$, content $5.81)$ at 8 levels of $\mathrm{N}$ supply $(0,5,10,15,25,40,60$ and $80 \mathrm{mmol} \mathrm{N}$ per pot per cut; increasing shoot yield indicates increase in $\mathrm{N}$ supply). 5 cuts harvested; root weight determined after final cut. (Data from Blanken, 1983.)

that the difference in production between the competing clones is greater without root partitioning than with root partitioning.

In another trial clone 39 was grown in combination with each of four other types of perennial ryegrass, without or with partitioning of the root systems. When the roots could compete with each other, clone 39 gained from the other types. Without root competition the yield of clone 39 was similar to that of the other types.

The relation between root mass and competitive ability was further investigated in two trials on competition between perennial ryegrass and couchgrass (Elytrigia repens (L.) Desv.; syn. Agropyron repens (L.) Beauv.) and described by Baan Hofman \& Ennik (1982). Some additional information on the root yields of the ryegrass types in monoculture in one of these trials has become available. Besides in pots (Baan Hofman \& Ennik, 1982: Trial II) monocultures of the ryegrass types were grown in trays in the same way as the mixtures. Whereas in the pots clone 160 had a large root mass with a relatively small proportion of roots in the topsoil layer, the root mass of this clone in the trays was small and of the same size as that of clone 40 . The relation between shoot and root mass of the ryegrass types in monoculture at the end of the third season is shown in Fig. 5 (left). It is similar to that for intermittent nutrient supply: little variation in herbage yield, but a great variation in root mass, reflecting the differences in genetic constitution of the ryegrass, e.g. between clones 39 and 40 . Selections I and X were recently developed by the Foundation for Agricultural Plant Breeding in Wageningen. They were selected because of their good persistence and competitive ability (Ennik et al., 1980). Although root mass was not used as a selection criterion, they apparently have a relatively large root mass. The relatively small root mass of the cultivar 'Pelo' in this trial was not always found in later trials.

Fig. 5 (right) demonstrates the effect of the root mass of the ryegrass on the con- 

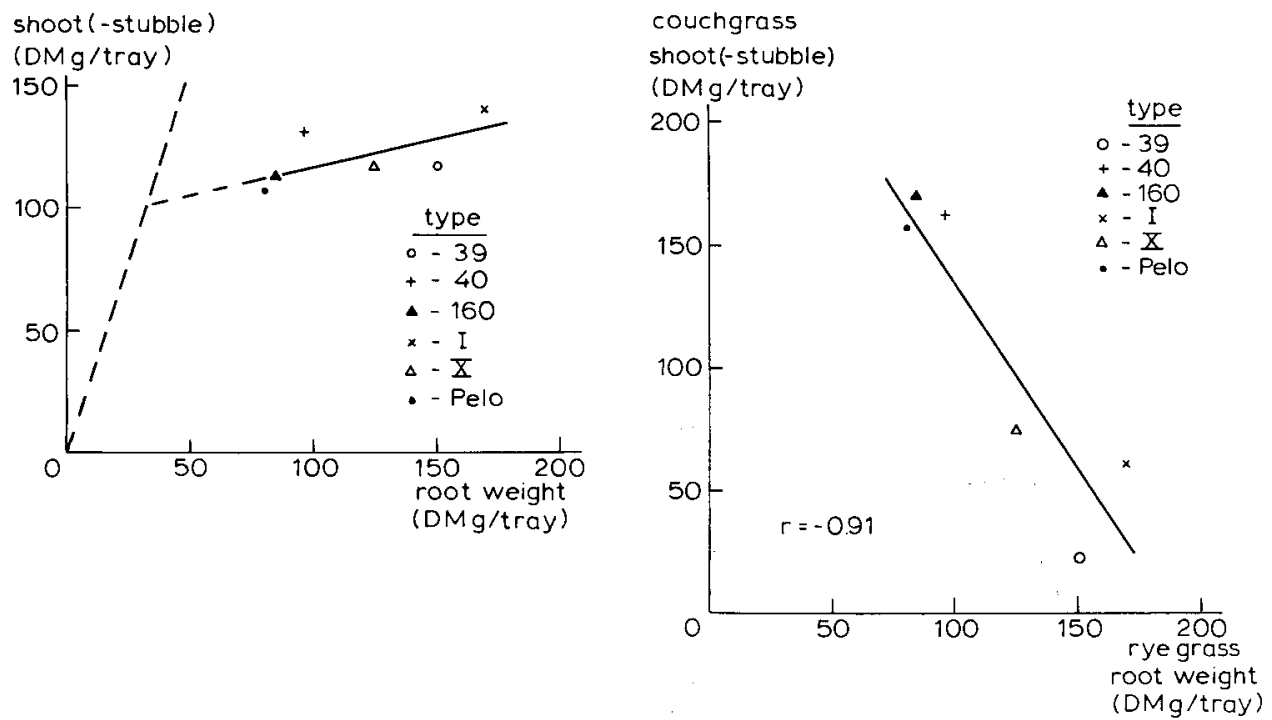

Fig. 5. Left: shoot-root relationship of 6 types of perennial ryegrass in monoculture at the end of the 3rd season: shoot yield 5th cut 1981, 24 September; root weight $(0.30 \mathrm{~cm})$ November 1981 . Right: relationship between the root mass of perennial ryegrass types in monoculture and the herbage yield of couchgrass in the corresponding mixtures (5th cut 1981). (Baan Hofman \& Ennik: Trial II plus additional data.)

Ryegrass clones 39, 40 and 160, selections I and X, and cv. 'Pelo' were planted outdoors in monoculture in sandy soil in trays of $80 \mathrm{~cm}$ square and $30 \mathrm{~cm}$ deep in June 1979, per tray 100 clusters of 4 tillers each. In a parallel series, one week after planting the ryegrass, 8 clusters of couchgrass, of 5 tillers each, were planted between the ryegrass. 2 replicates per treatment. 2 cuts were taken in 1979,4 in 1980 and 5 in 1981. N, P and K fertilizer were supplied at a rate of 120,90 and $120 \mathrm{~kg}$ per ha per cut, respectively. In 1981 no fertilizer was applied at the 1st cut (Trial 569.3).

tribution of couchgrass in the mixture. The higher the root mass of the ryegrass (measured in monoculture), the lower the yield of couchgrass in the mixture.

\section{General conclusions on the variation in root mass and its ecological consequences}

It has been shown (Fig. 4) that with increasing rates of fertilizer $\mathbf{N}$ root mass increased at the lower $\mathrm{N}$ rates, but decreased at the higher $\mathrm{N}$ rates. Similar results have been reported earlier (Ennik et al., 1980). The $\mathrm{N}$ rate for maximum root growth depends on light intensity. With a higher light intensity, maximum root growth is achieved at a higher $\mathbf{N}$ rate (Brouwer, 1962), which is attributed to an improved carbohydrate supply to the roots.

In pot trials with increasing levels of $N$ supply Dirven \& Wind (1982) found that besides root mass the contents of water-soluble carbohydrates in shoot, stubble and root increased at the lower rates of $\mathrm{N}$, and decreased at higher rates. However, the $\mathrm{N}$ rate for maximum root mass did not quite coincide with the $\mathrm{N}$ rate for maximum carbohydrate content. They also found that the maximum root production of the more productive grass species and varieties occurred at a higher $\mathbf{N}$ rate than that of 
the less productive species and varieties, the high producers also having a higher water-soluble-carbohydrate content.

In a field trial Ennik et al. (1980) found that with a $\mathrm{N}$ supply of $660 \mathrm{~kg}$ per ha root mass was about half of that with a $\mathrm{N}$ supply of $165 \mathrm{~kg}$ per ha, indicating that under our climatic conditions maximum root mass of perennial ryegrass in the field is achieved at a low level of $N$ supply.

After defoliation root growth stops until the original shoot/root ratio has been restored. When the period between two defoliations is fully needed to restore this ratio, root mass does not increase further. So at constant $\mathrm{N}$ supply root mass is closely related to the frequency of defoliation: less frequent defoliation will result in a larger root mass, more frequent defoliation in a smaller root mass.

Since differences in shoot/root ratio between the clones did not occur in the first cut, but only in later cuts (Fig. 3, upper part), the question arises whether this change with time is brought about by physiological causes within the plant or by changes in the environment. Short periods of limiting nutrient supply suffice to increase root growth (Section 1). Perhaps, in spite of the fact that the main nutrients were supplied after each cut, the nutrient supply in our trials might not always have been optimal. There is evidence that at least in Trial 516.06 (Fig. 3) potassium was in short supply at the end of the season. This could imply that the genetic variation in root mass might not manifest itself when nutrients are in full supply.

In agreement with this suggestion, in some trials in which ryegrass cultivars were grown on nutrient solution with nutrients in full supply, a similar shoot/root ratio for all pots of the same cut was still present after several defoliations (Fig. 1). On the other hand, in a pot trial with perennial ryegrass clones grown on a half-strength Hoagland solution, which was renewed rather frequently, root mass and shoot/root ratio varied markedly at the end of the season.

The results in Fig. 4 suggest that genetic differences in root mass also occur with full $\mathrm{N}$ supply for shoot growth, but that they are small compared to those found at moderate $\mathrm{N}$ supply.

The relation between root mass and competitive ability, reported in Section 4, was also found in earlier trials (Baan Hofman \& Ennik, 1980). It was shown by Spitters (1983) that the share a genotype gains in a mixture is closely related to its starting position. Under conditions of full nutrient supply an explanation for the relation between root mass and competitive ability could be, that after defoliation plants with a larger root mass may have more reserves available for regrowth. This is much more effective in mixture than in monoculture, in a similar way as described for differences in seedling weight of 12 wheat varieties, which had hardly any effect on final yield in monoculture, but highly affected the contribution in mixture (Spitters, 1983, and personal communication). In this hypothesis the effect of roots on competition is indirect: a difference in starting position between the above-ground parts in the competition for light, induced by the difference in root mass.

In stress situations plants with a large root mass may obtain a greater part of the 
limiting nutrient. This is a direct effect of roots on competition. Such an effect was apparent in the trials with and without root partitioning, as the differences in competitive ability between the clones were greater without that with root partitioning. If the increase in competitive ability with increasing root mass is (partly) due to a higher amount of reserves after defoliation, than with root partitioning clone 39 would also gain on the other clones. This was the case in Trial 516.06 (Fig. 3, lower part), but not in the other trial reported in Section 4 in which, without root competition, shoot yield of clone 39 was comparable to that of the other perennial ryegrass types.

The main ecological consequence of the variation in root mass probably is the effect on competitive ability: the larger the root mass of a plant or a variety, compared with other plants or varieties of the same species, the greater its competitive ability. From an agricultural point of view a larger root mass is an advantage in preventing or diminishing the ingress of undesired species such as couchgrass. In mixed swards a larger root mass of the grasses may be a disadvantage, because of the greater aggressiveness against desired companion species such as white clover.

For a monoculture under optimal growth conditions a small root mass may be advantageous to the farmer, because theoretically a greater part of the dry matter produced can be invested in the harvestable plant parts. In our experiments the lower root mass of clone 40 relative to clone 39 , however, did not result in a higher herbage yield. Under suboptimal growth conditions, when water or soil nutrients are in short supply, a large root mass may be useful. It is stated by Garwood \& Sinclair (1979) that the main characteristic for the ability of grasses to withstand periods of drought, is the extent to which their root systems explore the soil for water. According to Troughton (1974) a large root system would only be an advantage, if it enables the plant to have access to a larger quantity of water, e.g. by being deeper rooted. But in a limited volume of soil a large root system would be a disadvantage, because the water is exhausted sooner.

Van Noordwijk (1983) demonstrated that a dense root system can better extract the plant's needs from a poor soil than a poor root system. Increasing the root density seems to have the highest beneficial effect on $P$ nutrition. In a pot trial with the ryegrass clones 39 and 40 in monoculture he found that with limited $P$ supply herbage yield of clone 39 , with the largest root mass, was considerably higher than the yield of clone 40 , with the smaller root system. With full $\mathbf{P}$ supply herbage yield of both clones was equally high. In contrast to the effect of limited P supply, herbage yield of the two clones was the same with limited N supply (Fig. 4), because of the greater mobility of $\mathrm{N}$ relative to $\mathrm{P}$ in the soil. The transport of $\mathrm{N}$ in the soil to the root normally involves very small gradients, so that the concentration of $\mathrm{N}$ at the root surface will be nearly identical to the average concentration in the soil layer (van Noordwijk, 1983). 


\section{G. C. ENNIK AND T. BAAN HOFMAN}

\section{References}

Baan Hofman, T. \& G. C. Ennik, 1980. Investigation into plant characters affecting the competitive ability of perennial ryegrass (Lolium perenne L.). Neth. J. agric. Sci. 28: 97-109.

Baan Hofman, T. \& G. C. Ennik, 1982. The effect of root mass of perennial ryegrass (Lolium perenne L.) on the competitive ability with respect tot couchgrass (Elytrigia repens (L.) Desv.). Neth. J. agric. Sci. 30: 275-283.

Blanken, P., 1983. Boven- en ondergrondse produktie van 2 klonen van Engels raaigras (Lolium perenne L.) en echte witbol (Holcus lanatus Sibth.) bij toenemende bemesting. Proefverslag Vakgroep Landbouwplantenteelt en Graslandkunde, Wageningen.

Brouwer, R., 1962. Nutritive influences on the distribution of dry matter in the plant. Neth. J. agric. Sci. 10: 399-408.

Dirven, J. G. P. \& K. Wind, 1982. De invloed van bemesting op de beworteling van verschillende grassoorten en -rassen. Mededeling no. 61 Vakgroep Landbouwplantenteelt en Graslandkunde, Wageningen, $36 \mathrm{pp}$.

Ennik, G. C., 1966. Influence of clipping and soil fumigation on shoot and root production of perennial ryegrass and white clover. Jaarb. Inst. biol. scheik. Onderz. Landbouwgewass. 1966: 11-18.

Ennik, G. C., M. Gillet, \& L. Sibma, 1980. Effect of high nitrogen supply on sward deterioration and root mass. In: W. H. Prins \& G. H. Arnold (Eds). The role of nitrogen in intensive grassland production. Proc. int. Symp. Eur. Grassl. Fedn (Wageningen). Pudoc, Wageningen, pp. 67-76.

Garwood, E. A. \& J. Sinclair, 1979. Use of water by six grass species. 2. Root distribution and use of soil water. J. agric. Sci., Cambr. 93: 25-35.

Noordwijk, M. van, 1983. Functional interpretation of root densities in the field, for nutrient and water uptake. In: Root ecology and its practical application. Proc. int. Symp., Irdning (Austria) 1982 (in press).

Spitters, C. J. T., 1983. Effects of intergenotypic competition in the selection process. Proc. 10th Eucarpia Congress, June 1983, Wageningen (in prep.).

Troughton, A., 1974. The growth and function of the root in relation to the shoot. In: J. Kolek (ed.). Structure and function of primary root tissues. Proc. Symp. Tatraská Lomnica 1971 (Bratislava), pp. 153-164. 